\title{
ORGANIZATIONAL TRUST IN HOSPITALS: A MODEL STUDY ${ }^{1}$
}

\section{HASTANELERDE ÖRGÜTSEL GÜVEN: BIIR ÖRNEK UYGULAMA}

\author{
Haluk ŞENG $\ddot{U} N^{1}$, Selma SÖYÜU ${ }^{2}$ \\ ${ }^{1}$ Bahçeşehir University, Faculty of Health Sciences, Department of Health Management, İstanbul / Turkey \\ ${ }^{2}$ Istanbul University, Faculty of Health Sciences, Department of Health Management, İstanbul / Turkey
}

Öz: Bu çalışma sağlık çalışanlarının örgütsel güven düzeylerini belirlemek, örgütsel güven düzeyi ile sosyodemografik özellikleri arasındaki ilişkilerin belirlenmesine yönelik hazırlanmıştır. Araştırma sağlık çalışanlarının sosyo-demoğrafik özeliklerini tanımlayan bir anket formu ile örgütsel güven ölçeğinden oluşmuş tanımlayıcı bir çalışmadır. Veriler, araştırmaya katılmaya istekli, iki özel hastaneden, toplamda 534 sağlık çalışanından elde edilen, 409 adet geçerli anket ile yapılmıştır. Örneklem seçimi tesadüfi olarak belirlenmiştir. Örgütsel güven boyutları ile ilgili bulgular değerlendirildiğinde; her güven boyutunun bölümlere göre farklılık gösterdiği, yöneticiye güvenin en çok acil yoğun bakım bölümde, kuruma güvenin çocuk hastalıkları bölümünde, çalışma arkadaşlarına güvenin ise cerrahi bilimlerde en yüksek olduğu belirlenmiştir. Çalışma arkadaşlarına güven en yüksek kadın çalışanlarda çıkmıştır. Yöneticiye güven kuruma ve yaşa göre farklılaşmaktadır. Kuruma güven mesleki deneyime göre en yüksek ortalama 1-5 yıl grubuna aittir. Yöneticiye güven çalışma şekline göre en yüksek sadece gündüz çalışanlarına aittir. Kuruma güven çalışma şekline göre en yüksek nöbet usulü çalışanlarda yüksek çıkmıştır.

Anahtar Kelimeler: Güven, İlişki, Örgüt, Boyut, Sağlık, Çalışan, Hastane, Kurum, Düzey
Abstract: This study was conducted to determine the levels of organizational trust of health workers and to determine the relations between their levels of organizational trust and sociodemographic characteristics. This is a descriptive study comprising of the organizational trust scale and a questionnaire form identifying the socio-demographic characteristics of health workers. Data were collected through 409 valid questionnaires obtained from 534 health workers from two private hospitals, who volunteered to participate in the research. The sample was randomly selected. An evaluation of the findings related to the dimensions of organizational trust demonstrates that each dimension of trust varies by department, with the highest trust in supervisor being in the department of emergency intensive care, the highest trust in the institution being in the department of pediatrics, and the highest trust in coworkers being in the department of surgical sciences. The highest trust in coworkers was found to be among female workers. Trust in supervisor varies by institution and age. The highest average trust in institution belongs to the group with an occupational experience of 1-5 years. Trust in supervisor varies by mode of work, with those who work only during daytime having the highest average. The highest trust in institution was found to be among those working in shifts as a mode of work

Key Words: Trust, Relation, Organization, Dimension, Health, Worker, Hospital, Institution, Level

Doi: $10.17363 /$ SSTB.20161816492

(1) Corresponding Author: Haluk ŞENGÜN, Bahçeşehir University, Faculty of Health Sciences, Department of Health Management, İstanbul / Turkey haluksengun@hotmail.com Received: 21.12.2015 Accepted: 16.03.2016 Type ofarticle (Research -Application) Conflict of Interest: None / "None of Ethics Committee" 


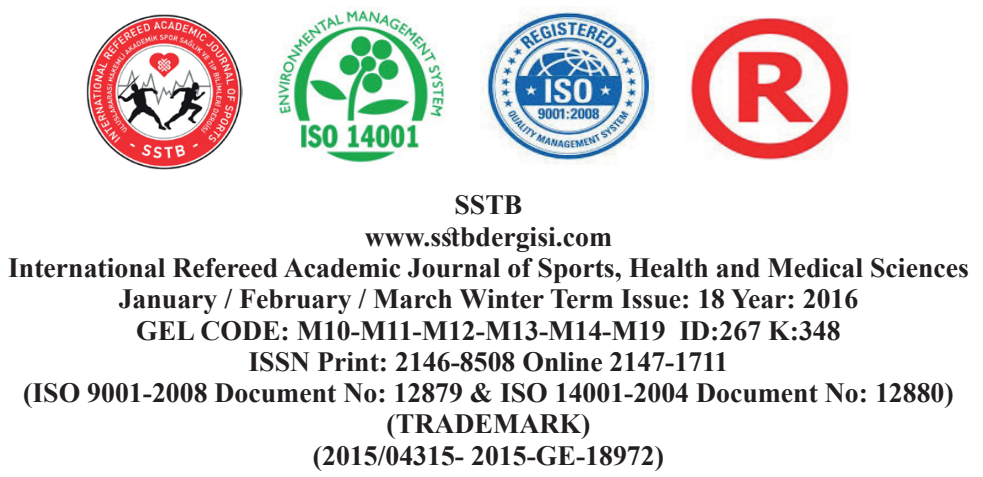

INTRODUCTION and THEORETICAL FRAMEWORK

Trust is a building block of organizations. There is no other variable that by itself influences individual's behavior as much as the concept of trust does (Hosmer and Tone, 1995: 379-381). It is one of the factors affecting the quality of interpersonal relations and organizational functioning to a significant extent. As "Trust, which is a social reality", as emphasized by Lewis (Lewis et al., 1985: 965-68), forms the basis for all bilateral relations. Trust is an internal movement resembling a behavioral intention or a choice (Colquitt et al., 2007: 910-925). Trust is composed of expectations, assumptions or beliefs that the future actions of another party will be favorable, beneficial, or at least, harmless (Kramer, 1999: 559-598). Researchers studying the concept of trust have usually defined it through such words as expectation, belief, risk-taking, predictability, vulnerability and dependence (Pain, 2007). The concept of trust is considered as a condition for social relations and stability in the light of interpersonal collaboration and solidarity (Demir, 2015: 624).

Organizational trust has been one of the major research topics of the management science for over three decades (Wahlstrom and Louis, 2008: 458). Organizational trust is defined as the willingness of an organization's employees to remain vulnerable to the ac- tions of the organization (Tan and Lim, 2009: 45). In other words, it is the trust and support felt by everyone working in an organization (Y1lmaz and Atalay, 2009: 341). Within the scope of this study, organizational trust is addressed under three dimensions, namely trust in institution, trust in supervisor, and trust in coworkers. These factors are related to and precursors of each other. Trust in institution is defined as the belief of workers in the coherence of the organization's behavior when they face a risky situation (Demircan and Ceylan, 2003, 142); trust in supervisor refers to their belief in the explanations and promises made by their supervisor (Deluga, 1994, 315), and trust in coworkers is defined as the belief of workers in the actions, honesty and good will of their fellow workers (Tokgöz and Aytemiz Seymen, 2003: 63). Developments acquired through high organizational trust can be listed as follows: The level of organizational justice increases; job satisfaction enhances; conflicts and job stress decrease, and the levels of organizational commitment and organizational citizenship escalate (Aykan, 2007; Polat, 2009). Perception of high trust enables the easy development of the organizational culture within the organization, and it keeps the communication channels more open and the behavior of engagement in collaboration at a higher level (Polat, 2009: 3-12). Employees with higher levels of trust have fewer intentions to quit their jobs and lower levels of ab- 


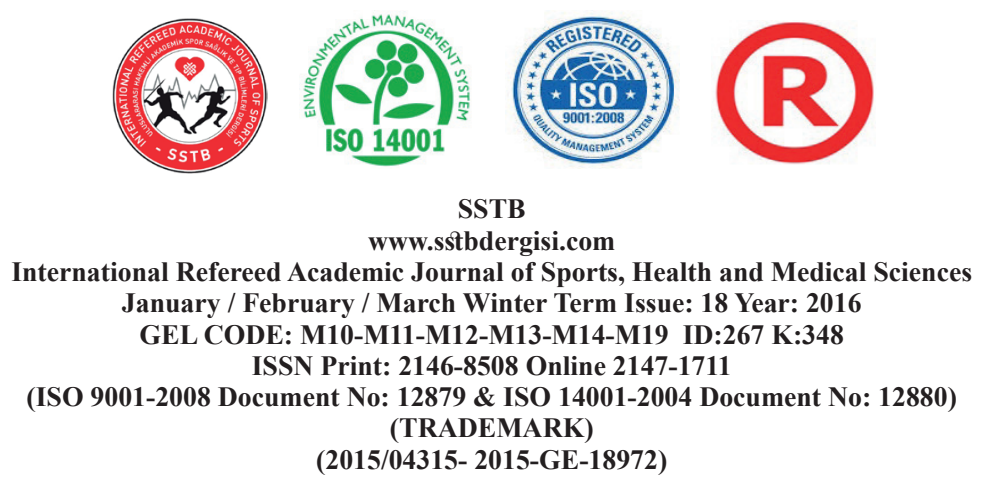

sence and labor turnover. Organizational trust enhances workers' morale, increases communication, strengthens the sharing among workers, and develops team spirit and team work. Conflict, job stress, and exhaustion decrease through organizational trust to be provided in the environment of an organization. It provides an observable increase in participation in decision making processes, problem-solving skills, creativity, social responsibility, and risk-taking behavior (Polat, 2009: 3-12 (Aykan, 2007: 159).

Organizations with higher levels of organizational trust have higher advantages in terms of productivity, individual performance of workers, organizational performance, and workers' commitment to the organization (Fard et al., 2010: 30). Trust is an institutional value that constructively develops individual relationships (Puusa and Alvanen, 2006: 2). Workers' trust in their organizations can cause them to be emotionally committed to their organizations, to have higher job satisfaction, not to complain about their organizations, and to be unwilling to leave quit their jobs (Dirks and Ferrin, 2002: 611-612; Chen et al., 2012: 409). If workers' sense of trust is harmed, this weakens their commitment to the organization, which may thereby cause them to quit their jobs or result in absence or lower performance (Mete and Aksoy, 2015: 234-237). A high level of organizational trust is found to cause high satisfaction and productivity among the staff (Schnake, 1991: 740-742). Organizational trust increases the motivation of the staff, ensures effective team work, and encourages open communication (DeFrank and Ivancevich, 1998: 55-62). Members of staff with high organizational commitment consider themselves as important players of the team (Jones and George, 1998: 531-540). In most cases, a high level of organizational trust has brought success in creating various organizational forms and organizational structures, strategic partnerships, harmonious and responsive teams, and effective crisis management (Zalabak et al., 2009: 35-37). Trust in organization refers to workers' belief in the coherence of their organization's commitments and behaviors when they are faced with an ambiguous or risky situation (Rodgers and Waymond, 2009: 83-90). In other words, it is a worker's perception of the support provided by his/her organization (Mishra et al., 1990: 443-450). It is quite important to create a culture based on an environment of trust in hospitals, where interpersonal relations are considered as relatively more influential on the organization's functioning. Workers' interaction with each other and with their supervisors is one of the most important factors affecting their satisfaction in such organizations as hospitals where functional dependence is high. For such interaction to be positive and for health workers to produce services with ex- 


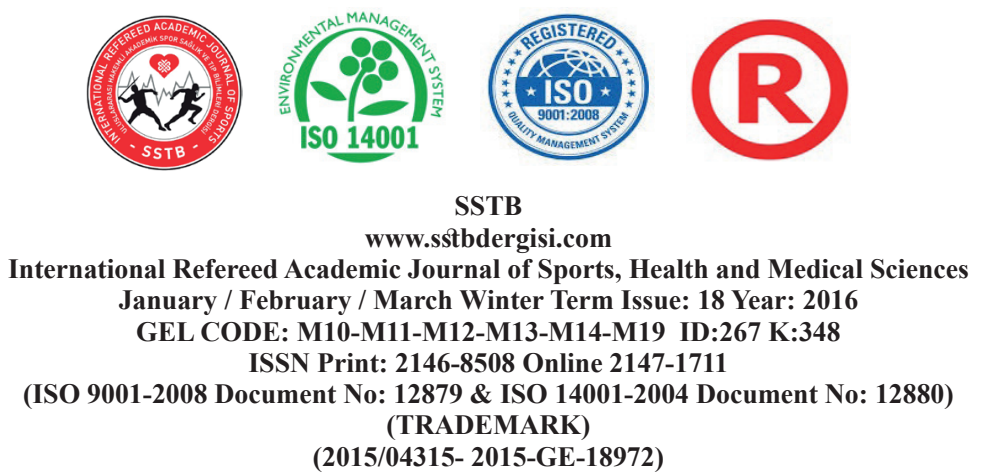

(2015/04315- 2015-GE-18972)

pected levels of quality and productivity, they should be, first of all, managed professionally and feel a sense of trust in their organization, supervisors and coworkers. In the health sector, there is a positive relation between organizational trust, organizational commitment and job satisfaction (Liou, 2008: 116-118). Increasing the organizational trust to higher levels in hospitals is only possible through the creation of an organizational structure that supports this condition. There is a need for the creation and implementation of personnel policies that will enable health managers and health workers to work in a more satisfied and productive way (Dursun, 2015: 134-155). Organizational trust, which has numerous positive outputs, should be kept sustainable and transformed into an organizational culture (Ayden and Özkan, 2014: 151). Otherwise, organizational distrust may cause many elements that will negatively affect the management process (Shouksmith, 1994). Therefore, hospital managements should systematically measure and evaluate the organizational trust among their staff and implement necessary policies and instruments to increase the level of trust (Tanner, 2007).

\section{Purpose}

409 health workers participated in this study, which aimed to measure organizational trust among health workers in a practical way. The study employed a questionnaire which included demographic and Likert-scaled questions. The data obtained from the questionnaire were analyzed through the SPSS Statistics 18 software, and the results and findings from the analysis are provided in the final part of the study.

\section{Analysis}

Descriptive statistics, reliability analysis, Factor Analysis, Man Whitney U, Kruskal Wallis, ANOVA, and t-test techniques were used for analysis. Cronbach's Alpha coefficient was calculated to be 0.957 .

\section{Method}

The target population of this study includes all the health workers working in private hospitals in the province of Istanbul. Five private institutions were randomly selected for the study, and only two of these institutions confirmed their participation. In the selection of the sample, respondents were required to have been working in their institutions for at least 6 months and to be high school graduates at minimum. Both institutions included 573 health workers meeting the requirements for this sample. Questionnaire forms were distributed to all of them, but 409 questionnaire forms were properly and completely filled in and received back.

\section{Data Collection Tools}

Survey method was employed as a tool for data collection. The questionnaire used for survey 


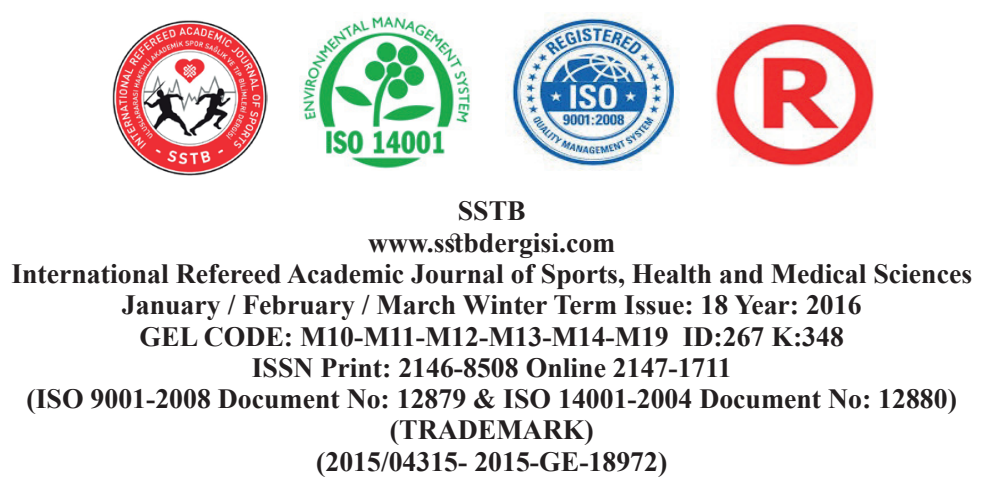

is made up of two parts. The first part questioned the sociodemographic and occupational characteristics of the health workers. This part includes 13 questions including "hospital of employment, position, department, mode of work, duty, duration of working in the workplace, total occupational experience, age, marital status, educational status, duty as a supervisor, management position of the supervisor, satisfaction from the job, status of considering to quit the job if deemed possible, gender, mode of working, working pattern, level of satisfaction from the job, and the status of considering to quit the job". The second part of the questionnaire is made up of the organizational trust scale. Organizational Trust Scale (OTS) is a 6-point Likert scale composed of 43 items with the options "strongly agree: 6 , agree: 5 , somewhat agree: 4 , somewhat disagree: 3 , disagree: 2, strongly disagree: 1". Organizational Trust Scale is composed of 3 sub-dimensions, namely trust in superiors, trust in organizational management and trust in coworkers. In our study, we adapted these three sub-dimensions as trust in supervisor, trust in institution and trust in coworkers.

OTS was developed by Altuntaş in 2008. Altuntaş used this scale in his doctoral study titled "relation between nurses' levels of organizational trust, and personal-occupational characteristics and organizational citizenship behaviors".

\section{Research Hypotheses}

$\mathrm{H} 1$ : Organizational trust factors of health workers do not vary by department.

$\mathrm{H} 2$ : Organizational trust factors of health workers do not vary by gender.

H3: Organizational trust factors of health workers do not vary by institution.

H4: Organizational trust factors of health workers do not vary by age.

H5: Organizational trust factors of health workers do not vary by occupational experience.

H6: Organizational trust factors of health workers do not vary by mode of work.

H7: Organizational trust factors of health workers do not vary by educational status.

\section{Implementation and Analyses}

\section{Reliability Analysis}

Table1. Reliability Analysis

\begin{tabular}{|l|l|}
\hline Cronbach's Alpha & Number of Items \\
\hline, 957 & 43 \\
\hline
\end{tabular}

The results of the reliability analysis show that the 43 items included in the analysis have a very high level of reliability.

\section{Demographic and Descriptive Statistics}

Demographic and descriptive statistics of the participants are provided below: 
SSTB

www.sstbdergisi.com

International Refereed Academic Journal of Sports, Health and Medical Sciences

January / February / March Winter Term Issue: 18 Year: 2016

GEL CODE: M10-M11-M12-M13-M14-M19 ID:267 K:348

ISSN Print: 2146-8508 Online 2147-1711

(ISO 9001-2008 Document No: 12879 \& ISO 14001-2004 Document No: 12880)

(TRADEMARK)

(2015/04315- 2015-GE-18972)

\begin{tabular}{|c|c|c|c|}
\hline \multicolumn{2}{|c|}{ Table 2. Demographic and Descriptive Statistics } & \multirow{2}{*}{$\begin{array}{r}\text { Frequency } \\
19\end{array}$} & \multirow{2}{*}{$\begin{array}{r}\text { Column N } \\
\% \\
5 \%\end{array}$} \\
\hline Your department & Internal medicine & & \\
\hline & Surgical sciences & 31 & $8 \%$ \\
\hline & Radiology & 16 & $4 \%$ \\
\hline & Emergency intensive care & 77 & $19 \%$ \\
\hline & Pediatrics & 20 & $5 \%$ \\
\hline & Orthopedics & 6 & $1 \%$ \\
\hline & Laboratory & 16 & $4 \%$ \\
\hline & Administrative units & 29 & $7 \%$ \\
\hline & Psychiatry & 2 & $0 \%$ \\
\hline & Gynecology & 22 & $5 \%$ \\
\hline & other & 171 & $42 \%$ \\
\hline \multirow[t]{4}{*}{ Mode of work } & Only daytime & 229 & $56 \%$ \\
\hline & In shifts & 172 & $42 \%$ \\
\hline & Only nighttime & 6 & $1 \%$ \\
\hline & Daytime and in case of necessity & 1 & $0 \%$ \\
\hline \multirow[t]{14}{*}{ You position } & Physician & 51 & $12 \%$ \\
\hline & Nurse & 70 & $17 \%$ \\
\hline & Technician & 42 & $10 \%$ \\
\hline & EMT & 53 & $13 \%$ \\
\hline & Supervisor & 10 & $2 \%$ \\
\hline & Civil servant & 33 & $8 \%$ \\
\hline & Servant & 32 & $8 \%$ \\
\hline & Midwife & 7 & $2 \%$ \\
\hline & Other & 43 & $11 \%$ \\
\hline & Medical secretary & 40 & $10 \%$ \\
\hline & Aesthetician / beautician & 4 & $1 \%$ \\
\hline & Security officer & 5 & $1 \%$ \\
\hline & Laboratorian & 13 & $3 \%$ \\
\hline & Ambulance driver & 6 & $1 \%$ \\
\hline \multirow[t]{4}{*}{ Duration of work in the workplace } & Less than 1 year & 132 & $32 \%$ \\
\hline & $1-5$ years & 246 & $60 \%$ \\
\hline & 6-10 years & 30 & $7 \%$ \\
\hline & 11 or more & 1 & $0 \%$ \\
\hline
\end{tabular}


SSTB

www.sstbdergisi.com

International Refereed Academic Journal of Sports, Health and Medical Sciences

January / February / March Winter Term Issue: 18 Year: 2016

GEL CODE: M10-M11-M12-M13-M14-M19 ID:267 K:348

ISSN Print: 2146-8508 Online 2147-1711

(ISO 9001-2008 Document No: 12879 \& ISO 14001-2004 Document No: 12880)

(TRADEMARK)

(2015/04315- 2015-GE-18972)

\begin{tabular}{|c|c|c|c|}
\hline \multirow[t]{4}{*}{ Total occupational experience } & Less than 1 year & 68 & $17 \%$ \\
\hline & $1-5$ years & 181 & $44 \%$ \\
\hline & $6-10$ years & 89 & $22 \%$ \\
\hline & 11 or more & 71 & $17 \%$ \\
\hline \multirow[t]{4}{*}{ Your age } & Younger than 25 & 150 & $37 \%$ \\
\hline & $25-29$ years & 96 & $23 \%$ \\
\hline & $30-34$ years & 76 & $19 \%$ \\
\hline & 35 or older & 87 & $21 \%$ \\
\hline \multirow[t]{2}{*}{ Your marital status } & Married & 192 & $47 \%$ \\
\hline & Single & 217 & $53 \%$ \\
\hline \multirow[t]{5}{*}{ Your educational status } & Vocational high school of health & 202 & $49 \%$ \\
\hline & Associate degree & 91 & $22 \%$ \\
\hline & Bachelor's degree & 62 & $15 \%$ \\
\hline & Specialization in medicine & 39 & $10 \%$ \\
\hline & Master's degree-doctorate & 15 & $4 \%$ \\
\hline \multirow[t]{2}{*}{ Are you at a management position? } & Yes & 58 & $14 \%$ \\
\hline & No & 347 & $86 \%$ \\
\hline \multirow[t]{8}{*}{ If you are a manager (supervisor) } & Chief physician & 4 & $1 \%$ \\
\hline & Chief nurse & 1 & $0 \%$ \\
\hline & Deputy director & 1 & $0 \%$ \\
\hline & Supervisor & 2 & $0 \%$ \\
\hline & Supervisor nurse & 17 & $4 \%$ \\
\hline & Chief manager & 8 & $2 \%$ \\
\hline & Other & 28 & $7 \%$ \\
\hline & Not manager & 348 & $85 \%$ \\
\hline \multirow[t]{2}{*}{ Are you satisfied with your job? } & Yes & 352 & $86 \%$ \\
\hline & No & 57 & $14 \%$ \\
\hline \multirow{2}{*}{$\begin{array}{l}\text { Would you consider quitting your job if } \\
\text { you had the opportunity? }\end{array}$} & Yes & 199 & $49 \%$ \\
\hline & No & 210 & $51 \%$ \\
\hline \multirow[t]{2}{*}{ Your gender } & Female & 260 & $64 \%$ \\
\hline & Male & 149 & $36 \%$ \\
\hline Province & Ordu & 409 & $100 \%$ \\
\hline \multirow[t]{2}{*}{ Institution } & Meditech & 219 & $54 \%$ \\
\hline & Medicalpark & 190 & $46 \%$ \\
\hline
\end{tabular}


www.sstbdergisi.com

International Refereed Academic Journal of Sports, Health and Medical Sciences

January / February / March Winter Term Issue: 18 Year: 2016

GEL CODE: M10-M11-M12-M13-M14-M19 ID:267 K:348

ISSN Print: 2146-8508 Online 2147-1711

(ISO 9001-2008 Document No: 12879 \& ISO 14001-2004 Document No: 12880)

(TRADEMARK)

(2015/04315- 2015-GE-18972)

\section{FACTOR ANALYSIS}

The responses of the respondents were evaluated, and a factor analysis was applied. Following factors were obtained in consequence of the analysis. A total of 43 items, responded by the health workers in relation to organizational trust, were grouped into 3 factorial dimensions in consequence of the factor analysis:

1. Trust in supervisor

2. Trust in institution

3. Trust in coworkers

\begin{tabular}{|c|c|c|c|}
\hline \multirow{2}{*}{ Table 3. Factor Analysis } & \multicolumn{3}{|c|}{ Component } \\
\hline & 1 & 2 & 3 \\
\hline Trust in supervisor & .827 & & \\
\hline Trust in supervisor & .799 & & \\
\hline Trust in supervisor & .797 & & \\
\hline Trust in supervisor & .783 & & \\
\hline Trust in supervisor & .779 & & \\
\hline Trust in supervisor & .764 & & \\
\hline Trust in supervisor & .761 & & \\
\hline Trust in supervisor & .752 & & \\
\hline Trust in supervisor & .750 & & \\
\hline Trust in supervisor & .740 & & \\
\hline Trust in supervisor & .724 & & \\
\hline Trust in supervisor & .718 & & \\
\hline Trust in supervisor & .717 & & \\
\hline Trust in supervisor & .708 & & \\
\hline Trust in supervisor & .707 & & \\
\hline Trust in supervisor & .704 & & \\
\hline Trust in supervisor & .679 & & \\
\hline Trust in supervisor & .672 & & \\
\hline Trust in supervisor & .661 & & \\
\hline Trust in supervisor & .648 & & \\
\hline Trust in supervisor & .622 & & \\
\hline
\end{tabular}


SSTB

www.sstbdergisi.com

International Refereed Academic Journal of Sports, Health and Medical Sciences

January / February / March Winter Term Issue: 18 Year: 2016

GEL CODE: M10-M11-M12-M13-M14-M19 ID:267 K:348

ISSN Print: 2146-8508 Online 2147-1711

(ISO 9001-2008 Document No: 12879 \& ISO 14001-2004 Document No: 12880)

(TRADEMARK)

(2015/04315- 2015-GE-18972)

\begin{tabular}{|c|c|c|c|}
\hline Trust in supervisor & .482 & & \\
\hline Trust in institution & & .801 & \\
\hline Trust in institution & & .791 & \\
\hline Trust in institution & & .790 & \\
\hline Trust in institution & & .774 & \\
\hline Trust in institution & & .728 & \\
\hline Trust in institution & & .709 & \\
\hline Trust in institution & & .708 & \\
\hline Trust in institution & & .664 & \\
\hline Trust in institution & & .651 & \\
\hline Trust in institution & & .633 & \\
\hline Trust in institution & & .536 & \\
\hline Trust in institution & & .418 & \\
\hline Trust in coworkers & & & .793 \\
\hline Trust in coworkers & & & .791 \\
\hline Trust in coworkers & & & .788 \\
\hline Trust in coworkers & & & .779 \\
\hline Trust in coworkers & & & .769 \\
\hline Trust in coworkers & & & .654 \\
\hline Trust in coworkers & & & .650 \\
\hline Trust in coworkers & & & .468 \\
\hline Trust in coworkers & & & .402 \\
\hline
\end{tabular}


SSTB

www.sstbdergisi.com

International Refereed Academic Journal of Sports, Health and Medical Sciences

January / February / March Winter Term Issue: 18 Year: 2016

GEL CODE: M10-M11-M12-M13-M14-M19 ID:267 K:348

ISSN Print: 2146-8508 Online 2147-1711

(ISO 9001-2008 Document No: 12879 \& ISO 14001-2004 Document No: 12880)

(TRADEMARK)

(2015/04315- 2015-GE-18972)

\section{ANALYSES}

\begin{tabular}{|c|c|c|c|c|c|c|c|c|c|c|c|}
\hline \multicolumn{3}{|l|}{ Table 3. Analyses } & \multicolumn{3}{|c|}{$\begin{array}{l}\text { Communication with } \\
\text { superiors/supervisors }\end{array}$} & \multicolumn{3}{|c|}{$\begin{array}{l}\text { Communication within the } \\
\text { institution }\end{array}$} & \multicolumn{3}{|c|}{$\begin{array}{c}\text { Communication with } \\
\text { coworkers }\end{array}$} \\
\hline Department & $\mathbf{N}$ & $\%$ & Anova & SD & $\mathbf{p}$ & Anova & SD & $\mathbf{p}$ & Anova & SD & $\mathbf{p}$ \\
\hline Internal medicine & 19 & $5 \%$ & \multirow{11}{*}{1.961} & \multirow{11}{*}{1} & \multirow{11}{*}{0.036} & \multirow{11}{*}{0.418} & \multirow{11}{*}{1} & \multirow{11}{*}{0.038} & \multirow{11}{*}{1.315} & \multirow{11}{*}{1} & \multirow{11}{*}{0.022} \\
\hline Surgical sciences & 31 & $8 \%$ & & & & & & & & & \\
\hline Radiology & 16 & $4 \%$ & & & & & & & & & \\
\hline Emergency intensive care & 77 & $19 \%$ & & & & & & & & & \\
\hline Pediatrics & 20 & $5 \%$ & & & & & & & & & \\
\hline Orthopedics & 6 & $1 \%$ & & & & & & & & & \\
\hline Laboratory & 16 & $4 \%$ & & & & & & & & & \\
\hline Administrative units & 29 & $7 \%$ & & & & & & & & & \\
\hline Psychiatry & 2 & $0 \%$ & & & & & & & & & \\
\hline Gynecology & 22 & $5 \%$ & & & & & & & & & \\
\hline Other & 171 & $42 \%$ & & & & & & & & & \\
\hline Gender & $\mathbf{N}$ & $\%$ & $\begin{array}{l}\text { Man } \\
\text { Whitney U }\end{array}$ & SD & $\mathbf{P}$ & $\begin{array}{l}\text { Man } \\
\text { Whitney U }\end{array}$ & SD & $\mathbf{P}$ & $\begin{array}{l}\text { Man } \\
\text { Whitney U }\end{array}$ & SD & $\mathbf{P}$ \\
\hline Female & 260 & $64 \%$ & \multirow{2}{*}{-1.51} & \multirow[b]{2}{*}{1} & \multirow[b]{2}{*}{0.131} & \multirow[b]{2}{*}{-1.066} & \multirow[b]{2}{*}{1} & \multirow[b]{2}{*}{0.286} & \multirow[b]{2}{*}{-0.556} & \multirow[b]{2}{*}{1} & \multirow[b]{2}{*}{0.008} \\
\hline Male & 149 & $36 \%$ & & & & & & & & & \\
\hline Institution & $\mathbf{N}$ & $\%$ & t-test & SD & $\mathbf{P}$ & t-test & SD & $\mathbf{P}$ & t-test & SD & $\mathbf{P}$ \\
\hline Hospital A & 219 & $54 \%$ & \multirow[b]{2}{*}{0.067} & \multirow[b]{2}{*}{1} & \multirow[b]{2}{*}{0.047} & \multirow[b]{2}{*}{-0.757} & \multirow[b]{2}{*}{1} & \multirow[b]{2}{*}{0.045} & & & \\
\hline Hospital B & 190 & $46 \%$ & & & & & & & -0.678 & 1 & 0.498 \\
\hline Age & $\mathbf{N}$ & $\%$ & Anova & SD & $\mathbf{P}$ & Anova & SD & $\mathbf{P}$ & Anova & SD & $\mathbf{P}$ \\
\hline Younger than 25 & 150 & $37 \%$ & & & & & & & & & \\
\hline 25-29 years & 96 & $23 \%$ & & & & & & & & & \\
\hline 30-34 years & 76 & $19 \%$ & & & & & & & & & \\
\hline 35 or older & 87 & $21 \%$ & 1.945 & 3 & 0.022 & 0.769 & 3 & 0.012 & 1.743 & 3 & 0.016 \\
\hline Occupational experience & $\mathbf{N}$ & $\%$ & $\begin{array}{l}\text { Kruskal } \\
\text { Wallis }\end{array}$ & SD & $\mathbf{P}$ & $\begin{array}{l}\text { Kruskal } \\
\text { Wallis }\end{array}$ & SD & $\mathbf{P}$ & $\begin{array}{l}\text { Kruskal } \\
\text { Wallis }\end{array}$ & SD & $\mathbf{P}$ \\
\hline Less than 1 year & 68 & $17 \%$ & & & & & & & & & \\
\hline $1-5$ years & 181 & $44 \%$ & & & & & & & & & \\
\hline $6-10$ years & 89 & $22 \%$ & & & & & & & & & \\
\hline 11 or more & 71 & $17 \%$ & 1.979 & 3 & 0.577 & 11.974 & 3 & 0.007 & 4.986 & 3 & 0.173 \\
\hline Mode of work & $\mathbf{N}$ & $\%$ & Anova & SD & $\mathbf{P}$ & Anova & SD & $\mathbf{P}$ & Anova & SD & $\mathbf{P}$ \\
\hline
\end{tabular}




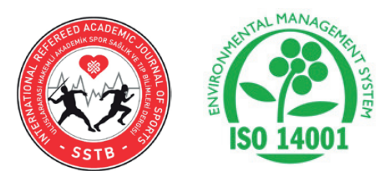

SSTB

www.sstbdergisi.com

International Refereed Academic Journal of Sports, Health and Medical Sciences

January / February / March Winter Term Issue: 18 Year: 2016

GEL CODE: M10-M11-M12-M13-M14-M19 ID:267 K:348

ISSN Print: 2146-8508 Online 2147-1711

(ISO 9001-2008 Document No: 12879 \& ISO 14001-2004 Document No: 12880)

(TRADEMARK)

(2015/04315- 2015-GE-18972)

\begin{tabular}{|c|c|c|c|c|c|c|c|c|c|c|c|}
\hline Only daytime & 229 & $56 \%$ & & & & & & & & & \\
\hline In shifts & 172 & $42 \%$ & & & & & & & & & \\
\hline Only nighttime & 6 & $1 \%$ & & & & & & & & & \\
\hline $\begin{array}{l}\text { Daytime and in case of } \\
\text { necessity }\end{array}$ & 1 & $0 \%$ & 1.955 & 3 & 0.001 & 0.873 & 3 & 0.048 & 0.025 & 3 & 0.999 \\
\hline Educational status & $\mathbf{N}$ & $\%$ & $\begin{array}{l}\text { Kruskal } \\
\text { Wallis }\end{array}$ & SD & $\mathbf{P}$ & $\begin{array}{l}\text { Kruskal } \\
\text { Wallis }\end{array}$ & SD & $\mathbf{P}$ & $\begin{array}{l}\text { Kruskal } \\
\text { Wallis }\end{array}$ & SD & $\mathbf{P}$ \\
\hline $\begin{array}{l}\text { Vocational high school of } \\
\text { health }\end{array}$ & 202 & $49 \%$ & & & & & & & & & \\
\hline Associate degree & 91 & $22 \%$ & & & & & & & & & \\
\hline Bachelor's degree & 62 & $15 \%$ & & & & & & & & & \\
\hline Specialization in medicine & 39 & $10 \%$ & & & & & & & & & \\
\hline Master's degree-doctorate & 15 & $4 \%$ & 2.244 & 4 & 0.691 & 3.982 & 4 & 0.408 & 2.097 & 4 & 0.718 \\
\hline
\end{tabular}

\section{H1: Organizational trust factors of health} workers do not vary by department.

A review of the organizational trust factors of health workers by department indicates that The sig values of all factors were found to be smaller than 0.05 ; therefore the hypotheses regarding these factors will be rejected. Accordingly,

- Trust in supervisors varies by department. The department of emergency intensive care has the highest average.

- Trust in institution varies by department. The department of pediatrics has the highest average.

- Trust in coworkers varies by department. The department of surgical sciences has the highest average.

\section{H2: Organizational trust factors of health} workers do not vary by gender.

A review of the organizational trust factors of health workers by gender indicates that only the 3rd factor has a Sig value smaller than 0.05 ; therefore, the hypothesis regarding this factor will be rejected. Accordingly,

- Trust in supervisors does not vary by gender.

- Trust in institution does not vary by gender.

- Trust in coworkers varies by gender. The female group has the highest average.

\section{H3: Organizational trust factors of health} workers do not vary by institution.

A review of the organizational trust factors of health workers by institution indicates that 1 st and 2nd factors have Sig values smaller 


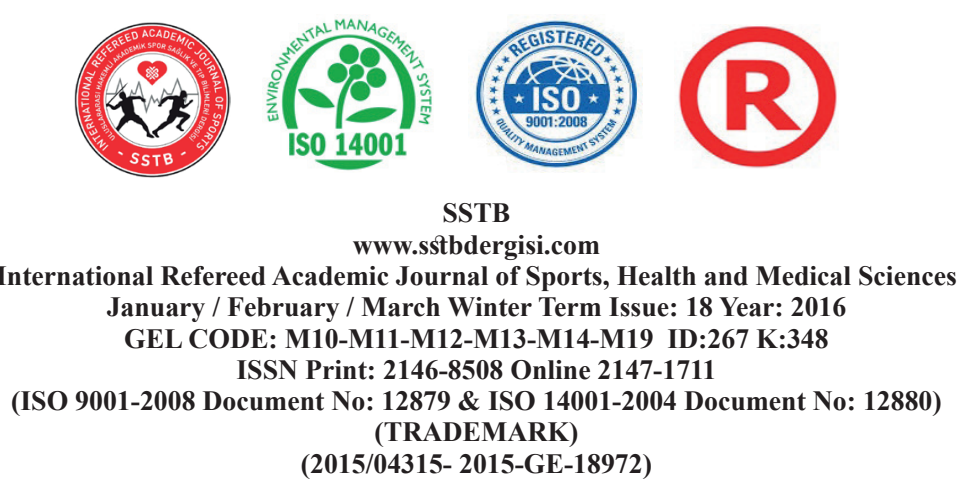

than 0.05 ; therefore, hypotheses regarding these factors will be rejected. Accordingly,

- Trust in supervisor varies by institution. Hospital A has the highest average.

- Trust in institution varies by institution. Hospital A has the highest average.

- Trust in coworkers does not vary by institution.

\section{H4: Organizational trust factors of health workers do not vary by age.}

A review of the organizational trust factors of health workers by age indicates that the sig values of all factors were found to be smaller than 0.05 ; therefore, the hypotheses regarding these factors will be rejected. Accordingly,

- Trust in supervisor varies by age. The highest average belongs to the group aged below 25 .

- Trust in institution varies by age. The highest average belongs to the age group 25-29.

- Trust in coworkers varies by age. The highest average belongs to the age group 25-29.

H5: Organizational trust factors of health workers do not vary by occupational experience.
A review of the organizational trust factors of health workers by occupational experience indicates that the sig values of all factors were found to be smaller than 0.05 ; therefore the hypotheses regarding these factors will be rejected. Accordingly,

- Trust in supervisor does not vary by occupational experience.

- Trust in institution varies by occupational experience. The highest average belongs to the group of 1-5 years.

- Trust in coworkers does not vary by occupational experience.

\section{H6: Organizational trust factors of health workers do not vary by mode of work.}

A review of the organizational trust factors of health workers by mode of work indicates that the 1 st and 2 nd factors have Sig values smaller than 0.05 ; therefore, hypotheses regarding these factors will be rejected. Accordingly,

- Trust in supervisor varies by mode of work. The highest average belongs to the group working only during daytime.

- Trust in institution varies by mode of work. The highest average belongs to the group working in shifts.

- Trust in coworkers does not vary by mode of work. 


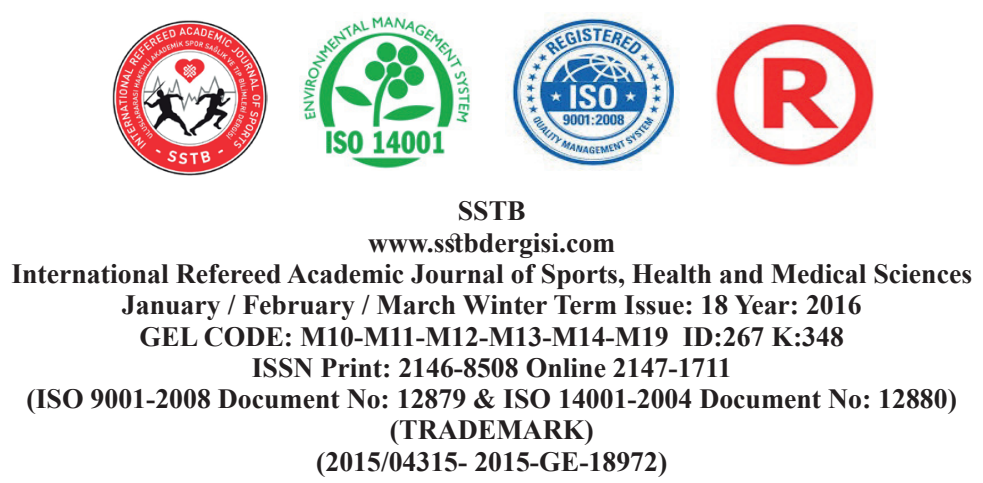

(2015/04315- 2015-GE-18972)

\section{H7: Organizational trust factors of health workers do not vary by educational status.}

A review of the organizational trust factors of health workers by educational status indicates that the sig values of all factors were found to be greater than 0.05; therefore, the hypotheses regarding these factors will be accepted. Accordingly,

- Trust in supervisor does not vary by educational status.

- Trust in institution does not vary by educational status.

- Trust in coworkers does not vary by educational status.

\section{CONCLUSION and ASSESSMENT}

- A total of 43 items, responded by the health workers in relation to organizational trust, were grouped into 3 factorial dimensions in consequence of the factor analysis:

1. Trust in supervisor

2. Trust in institution

3. Trust in coworkers

- Trust in supervisor varies by department. The highest average belongs to the department of emergency intensive care. Trust in institution varies by department. The department of pediatrics has the highest average. Trust in coworkers varies by depart- ment. The department of surgical sciences has the highest average.

- Trust in supervisor does not vary by gender. Trust in institution does not vary by gender. Trust in coworkers varies by gender. The female group has the highest average.

- Trust in supervisor varies by institution. Hospital A has the highest average. Trust in institution varies by institution. Hospital A has the highest average. Trust in coworkers does not vary by institution.

- Trust in supervisor varies by age. The highest average belongs to the group aged below 25. Trust in institution varies by age. The highest average belongs to the age group 25-29. Trust in coworkers varies by age. The highest average belongs to the age group 25-29.

- Trust in supervisor does not vary by occupational experience. Trust in institution varies by occupational experience. The highest average belongs to the group of 1-5 years. Trust in coworkers does not vary by occupational experience.

- Trust in supervisor varies by mode of work. The highest average belongs to the group working only during daytime. Trust in institution varies by mode of work. The highest average belongs to the group 


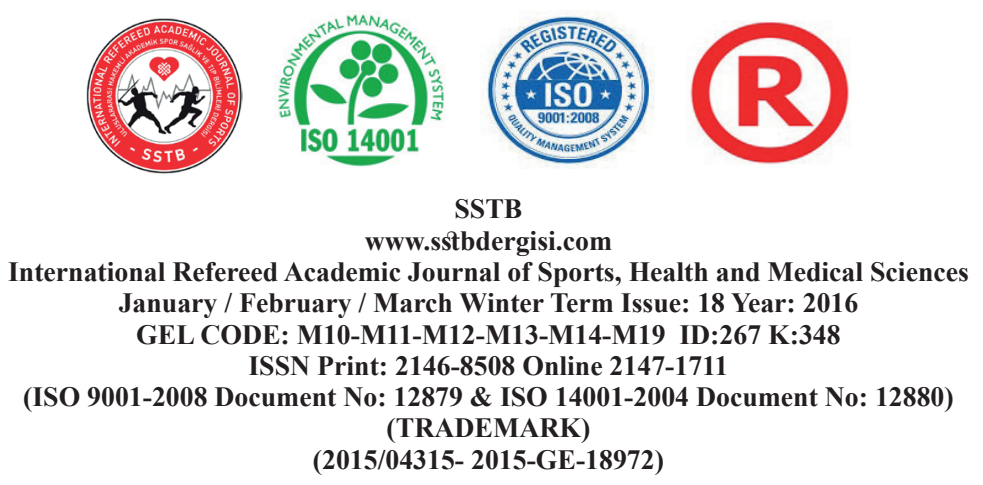

working in shifts. Trust in coworkers does not vary by mode of work.

- Trust in supervisor does not vary by educational status. Trust in institution does not vary by educational status. Trust in coworkers does not vary by educational status.

Managers should raise awareness about the concept of trust, which is recognized as the precondition of many positive developments for organizations; they should make improvements to support and sustain organizational trust at every opportunity, and they should carefully evaluate every aspect of organizational trust. Hospital management should treat health workers as a strategic element and create an organizational culture in which the interests of workers are protected and every worker is valued as an individual. Hospital managements must be able to keep the trust attitudes of their employees at high levels in order to provide successful management and to contribute to patient satisfaction, profitability and image of the hospital. For this purpose, the workers' responsibilities and duties should be clearly defined; the communication within the organization should be accurate, punctual and frequent; there should be a trust in the intraorganizational skills and capabilities for the works to be performed; shared goals

should be clear and comprehensible, and the organization should have a vision and goal. There should be consistency and integrity in managers' behaviors in order to gain employees' trust.

\section{REFERENCES}

AYDEN, C., ÖZKAN, Ö., (2014). Sağlık çalışanlarının kurumsal güven ve örgütsel bağlılık boyutları itibariyle incelenmesi; Malatya Devlet hastanesi sağlik personeli üzerine bir Çalışma, Fırat University Journal of Social Science 24,2:151-167

AYKAN, E., (2007). “Alg1lanan örgütsel destek ile örgütsel güven ve tükenme davranışı arasındaki ilişkilerin belirlenmesine yönelik bir araştırma”, 5. Ulusal Yönetim ve Organizasyon Kongresi, 2527 May 2007, Sakarya University, Sakarya

COLQUITT, J.A., et al., (2007). Trust, Trustworthiness, and Trust Propensity: A Meta-Analytic Test of Their Unique Relationships With Risk Taking and Job Performance. Journal of Applied Psychology, 92, 4, 910-925

DEFRAN, K.R, J., et al., 1998). Stress On The Job: An Executive Update. Academy of Management Executive, 12, 2, 55-62

DELUGA, R. J., (1994). Supervisor Trust Building, Leader-Member Exchange and 


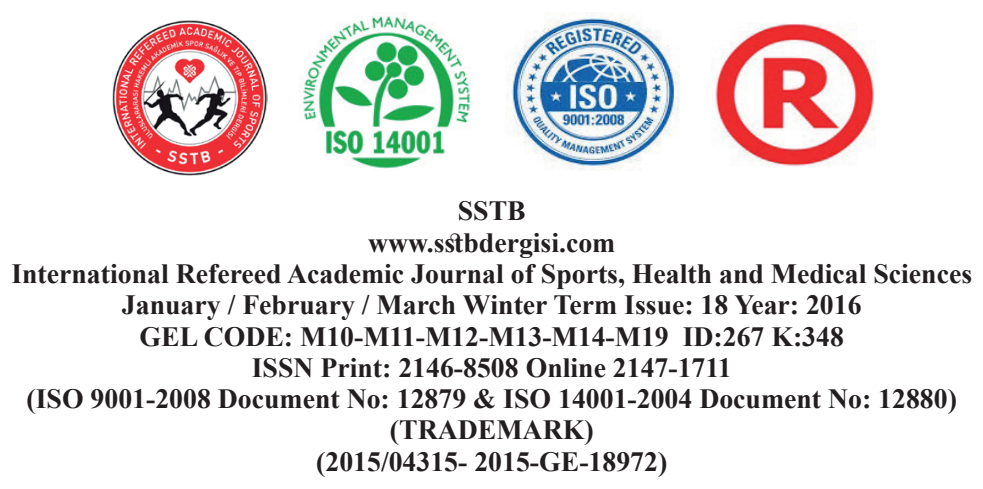

Organizational Citizenship Behavior. Journal of Occupational and Organizational Psychology, 67, 315-326. http:// dx.doi.org/10.1111/j.2044-8325.1994. tb00570.x

DEMIRCAN, N., CEYLAN, A., (2003). Örgütsel Güven Kavramı: Nedenleri ve Sonuçlar, Celal Bayar University, Faculty of Economics and Administrative Sciences, Yönetim ve Ekonomi Dergisi, Volume No 10, Issue 2.62-70

DEMIR, K., (2015) The Effect Of Organizational Trust On The Culture Of Teacher Leadership In Primary Schools, Educational Sciences: Theory and Practice 15(3): 624

DIRKS, K.T., et al., (2002), Trust in Leadership: Meta-Analytic Findings and Implications for Research and Practice, Journal of Applied Psychology, 87, 611-628

DURSUN, E., (2015) The Relation Between Organizational Trust, Organizational Support, and Organizational Commitment, African Journal of Business Management, 9(4): 134-155

FARD, H., et al., (2010). Organizational Trust in Public Sector: Explaining the Role of Managers ${ }^{\text {ee }}$ Managerial Competency, European Journal of Economics,
Finance and Administrative Sciences, ISSN 1450-2275 Issue 25, 29-43

HOSMER, L.T., (1995). Trust: The Connecting Link Between Organizational Theory and Philosophical Ethics. Academy of Management Review, 20, 2, 379-381

JONES.G, G.J., (1998). The Experience And Evolution of Trust: Implications for Cooperation and Teamwork. Academy of Management Review, 23, 3, 531-540

KRAMER, M.R., (1999). Trust and Distrust in Organizations: Emerging Perspectives, Enduring Questions. Annual Review of Psychology, 50, 569-598

LEWIS, J., et al, (1985). Trust as a Social Reality. Social Forces, 63, 965-968

LIOU.S., (2008) An Analysis of The Concept of Organizational Commitment. Nursing Forum,43, 3, 116-118

METE. M., AKSOY, C., (2015). Comparison of organizational commitment and organizational trust, in terms of justice perceptions of employees: an application on banking Electronic Journal of Social Sciences sector.14,54

MiSHRA, J., et al., (1990). Trust in Employee/Employer Relationships: A Survey of West Michigan Managers. Public Personnel Management, (19), 4, 443-450 


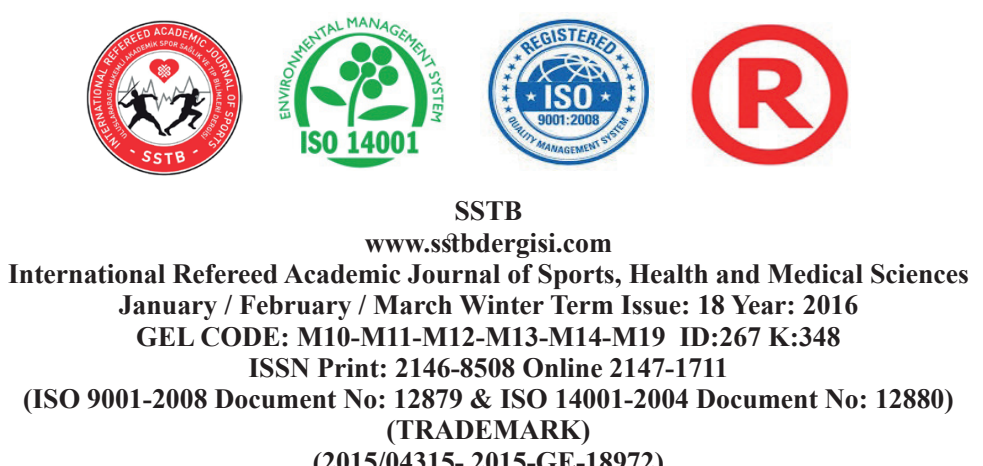

(2015/04315- 2015-GE-18972)

PAINE, S.C., (2007). The Relationship Among Interpersonal And Organizational Trust And Organizational Commitment. Doctoral dissertation. San Diego Alliant International University

POLAT, S., (2009) "Eğitim Örgütleri İçin Sosyal Sermaye: Örgütsel Güven”, Ankara: Pegem Akademi

PUUSA, A., et al, (2006) "Organizational Identity and Trust", Electronic Journal of Business Ethics and Organization Studies. Vol. 11, No. 2, 29-33

RODGERS, W., (2009). Three Primary Trust Pathways Underlying Ethical Considerations. Journal of Business Ethics, 91, 83-90

SCHNAKE.M , (1991). Organizational Citizenship: A Review, Proposed Model and Research Agenda. Human Relations, 44, 5, 735-759

SHOUKSMITH, G., (1994). Variables Related to Organizational Commitment In Health Professionals, Psychology Report, Vol:74 3, Part. 1, 1994

TAN, H. H., et al., (2009), Trust in Coworkers and Trust in Organizations, The Journal of Psychology, Volume 143, No 1

TANNER, B. M., (2007). An Analysis of the Relationships among Job Satisfaction,
Organizational Trust, and Organizational Commitment In An Acute Care Hospital, San Francisco, USA: Faculty of saybrook Graduate School and Research Center

TOKGÖZ, E., AYTEMIZZ SEYMEN, O. (2013). Örgütsel Güven, Örgütsel Özdeşleşme ve Örgütsel Vatandaşlık Davranışları Arasındaki İlişki: Bir Devlet Hastanesinde Araştırma. Marmara University Institute of Social Sciences Refereed Journal, 10 (39), 61-79

WAHLSTROM, K. L., et al., (2008). How Teachers Experience Principal Leadership: The Roles of Professional Community, Trust, Efficacy and Shared Responsibility, Educational Administration Quarterly, Volume 44, No 4

YILMAZ, A., and ATALAY, C. G., (2009). A Theoretical Analyze On The Concept of Trust in Organizational Life, European Journal of Social Sciences, Volume 8, No 2

ZALABAK, P.S., et al., (2009). Organizational trust: What It Means, Why It Matters. Organization Development Journal, (18), 4, 35-37 

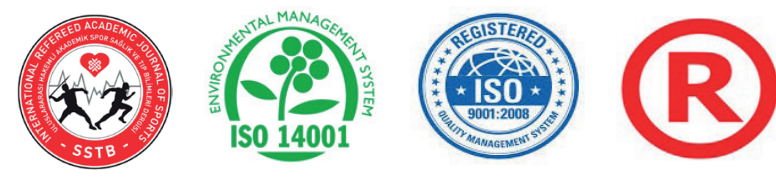

SSTB

www.sstbdergisi.com

International Refereed Academic Journal of Sports, Health and Medical Sciences January / February / March Winter Term Issue: 18 Year: 2016

GEL CODE: M10-M11-M12-M13-M14-M19 ID:267 K:348

ISSN Print: 2146-8508 Online 2147-1711

(ISO 9001-2008 Document No: 12879 \& ISO 14001-2004 Document No: 12880)

(TRADEMARK)

(2015/04315- 2015-GE-18972)

\section{ADDITIONAL TABLES}

\begin{tabular}{|c|c|c|c|c|c|c|}
\hline & Strongly disagree & Disagree & Somewhat disagree & Somewhat agree & Agree & Strongly agree \\
\hline & Row $\mathrm{N} \%$ & Row N\% & Row N\% & Row N\% & Row N\% & Row N\% \\
\hline $\begin{array}{l}\text { I believe that my superior will keep the promises hel } \\
\text { she makes }\end{array}$ & $8,3 \%$ & $7,6 \%$ & $11,2 \%$ & $26,2 \%$ & $28,1 \%$ & $18,6 \%$ \\
\hline My superior is an expert in hisher job & $6,6 \%$ & $9,0 \%$ & $8,1 \%$ & $20,3 \%$ & $33,7 \%$ & $22,2 \%$ \\
\hline My superior has knowledge enough to check the work I do & $5,4 \%$ & $8,1 \%$ & $7,8 \%$ & $17,6 \%$ & $35,9 \%$ & $25,2 \%$ \\
\hline I trust that my superior will make appropriate decisions & $6,1 \%$ & $7,1 \%$ & $8,3 \%$ & $24,0 \%$ & $35,5 \%$ & $19,1 \%$ \\
\hline My superior can develop team spirit & $7,1 \%$ & $8,6 \%$ & $8,8 \%$ & $21,0 \%$ & $35,0 \%$ & $19,6 \%$ \\
\hline $\begin{array}{l}\text { My superior can produce solutions for the problems I face } \\
\text { in my work }\end{array}$ & $5,4 \%$ & $6,1 \%$ & $8,8 \%$ & $24,2 \%$ & $35,2 \%$ & $20,3 \%$ \\
\hline $\begin{array}{l}\text { My superior defends me before the management when I } \\
\text { make a mistake }\end{array}$ & $9,3 \%$ & $9,0 \%$ & $9,5 \%$ & $26,7 \%$ & $29,1 \%$ & $16,4 \%$ \\
\hline I can share my personal problems with my superior & $11,0 \%$ & $14,2 \%$ & $9,0 \%$ & $20,8 \%$ & $27,4 \%$ & $17,6 \%$ \\
\hline My superior does not criticize me in my absence & $10,5 \%$ & $16,1 \%$ & $9,3 \%$ & $21,5 \%$ & $26,9 \%$ & $15,6 \%$ \\
\hline My superior does not show my work as hishher own work & $7,8 \%$ & $7,8 \%$ & $4,9 \%$ & $13,2 \%$ & $38,1 \%$ & $28,1 \%$ \\
\hline My superior behaves honestly to me & $5,6 \%$ & $7,1 \%$ & $7,6 \%$ & $19,8 \%$ & $35,5 \%$ & $24,4 \%$ \\
\hline My superior does not hide information from me & $10,3 \%$ & $8,8 \%$ & $9,5 \%$ & $21,8 \%$ & $31,3 \%$ & $18,3 \%$ \\
\hline My superior informs me about the decisions he/she makes & $7,1 \%$ & $7,1 \%$ & $7,3 \%$ & $22,5 \%$ & $36,4 \%$ & $19,6 \%$ \\
\hline $\begin{array}{l}\text { Itrust that my superior will not tell to others the information } \\
\text { I share with him her }\end{array}$ & $8,6 \%$ & $8,1 \%$ & $8,3 \%$ & $22,7 \%$ & $30,8 \%$ & $21,5 \%$ \\
\hline My superior tries to understand my thoughts & $7,1 \%$ & $8,3 \%$ & $9,5 \%$ & $24,7 \%$ & $34,2 \%$ & $16,1 \%$ \\
\hline $\begin{array}{l}\text { I know that my superior will approach constructively when I } \\
\text { tell him her my problems }\end{array}$ & $5,4 \%$ & $8,3 \%$ & $9,5 \%$ & $22,5 \%$ & $35,9 \%$ & $18,3 \%$ \\
\hline $\begin{array}{l}\text { My superior clearly expresses hisher expectations about my } \\
\text { occupational development }\end{array}$ & $5,4 \%$ & $8,8 \%$ & $8,8 \%$ & $20,8 \%$ & $35,9 \%$ & $20,3 \%$ \\
\hline $\begin{array}{l}\text { Ialways get feedback from my superior about the quality } \\
\text { of my work }\end{array}$ & $8,6 \%$ & $11,2 \%$ & $11,0 \%$ & $26,4 \%$ & $30,3 \%$ & $12,5 \%$ \\
\hline My superior is ready for help when I need him/her & $6,6 \%$ & $6,4 \%$ & $10,0 \%$ & $20,8 \%$ & $34,5 \%$ & $21,8 \%$ \\
\hline I have the freedom to disagree with my superior's views & $7,1 \%$ & $8,6 \%$ & $9,5 \%$ & $20,8 \%$ & $31,1 \%$ & $23,0 \%$ \\
\hline $\begin{array}{l}\text { My superior asks for my opinion when he/she will make } \\
\text { a decision }\end{array}$ & $11,2 \%$ & $12,5 \%$ & $10,5 \%$ & $24,4 \%$ & $27,6 \%$ & $13,7 \%$ \\
\hline $\begin{array}{l}\text { My superior views me as a human, rather than as a tool to } \\
\text { achieve the organization's goals }\end{array}$ & $8,6 \%$ & $8,6 \%$ & $12,0 \%$ & $18,3 \%$ & $31,3 \%$ & $21,3 \%$ \\
\hline $\begin{array}{l}\text { All the workers in our hospital tell the reality even if hearing } \\
\text { it will be displeasing }\end{array}$ & $19,6 \%$ & $13,7 \%$ & $13,2 \%$ & $26,4 \%$ & $18,3 \%$ & $8,8 \%$ \\
\hline The managers of our hospital are honest & $12,5 \%$ & $10,0 \%$ & $12,0 \%$ & $27,9 \%$ & $25,4 \%$ & $12,2 \%$ \\
\hline $\begin{array}{l}\text { Itrust that the managers of the hospital will make } \\
\text { appropriate decisions about the future of our hospital }\end{array}$ & $10,5 \%$ & $9,8 \%$ & $11,5 \%$ & $28,4 \%$ & $26,2 \%$ & $13,7 \%$ \\
\hline $\begin{array}{l}\text { Managers of our hospital clearly share the information about } \\
\text { the projects of the institution }\end{array}$ & $13,4 \%$ & $14,9 \%$ & $13,4 \%$ & $26,4 \%$ & $22,5 \%$ & $9,3 \%$ \\
\hline $\begin{array}{l}\text { The hospital management behaves farily with respect to } \\
\text { our personal rights }\end{array}$ & $13,9 \%$ & $14,7 \%$ & $12,7 \%$ & $24,9 \%$ & $26,2 \%$ & $7,6 \%$ \\
\hline Managers of the hospital have trust in all workers & $12,2 \%$ & $13,4 \%$ & $16,4 \%$ & $29,3 \%$ & $20,5 \%$ & $8,1 \%$ \\
\hline $\begin{array}{l}\text { The working hours and schedules in our hospital provide } \\
\text { sufficient time for the social lives of the workers }\end{array}$ & $20,3 \%$ & $13,9 \%$ & $14,9 \%$ & $23,0 \%$ & $18,1 \%$ & $9,8 \%$ \\
\hline $\begin{array}{l}\text { The institutional policies in our hospital are created in } \\
\text { consideration of the workers' opinions }\end{array}$ & $17,6 \%$ & $17,8 \%$ & $14,9 \%$ & $27,1 \%$ & $16,1 \%$ & $6,4 \%$ \\
\hline $\begin{array}{l}\text { Everybody in this hospital communicates openly with } \\
\text { each other }\end{array}$ & $13,4 \%$ & $16,6 \%$ & $13,7 \%$ & $24,2 \%$ & $22,5 \%$ & $9,5 \%$ \\
\hline $\begin{array}{l}\text { Employess do not refrain from expressing their suggestions } \\
\text { about institutional policies }\end{array}$ & $9,5 \%$ & $16,1 \%$ & $14,4 \%$ & $28,1 \%$ & $23,7 \%$ & $8,1 \%$ \\
\hline $\begin{array}{l}\text { In this hospital, everything functions transparently, and there } \\
\text { are no hiddden activities }\end{array}$ & $19,1 \%$ & $17,6 \%$ & $15,2 \%$ & $21,5 \%$ & $18,1 \%$ & $8,6 \%$ \\
\hline $\begin{array}{l}\text { I know that my coworkers will help me whenever I face a } \\
\text { challenge in my job }\end{array}$ & $4,4 \%$ & $5,6 \%$ & $8,8 \%$ & $19,1 \%$ & $35,0 \%$ & $27,1 \%$ \\
\hline $\begin{array}{l}\text { There are positive relations among the employes in the } \\
\text { hospital }\end{array}$ & $8,6 \%$ & $11,2 \%$ & $9,0 \%$ & $28,1 \%$ & $31,1 \%$ & $12,0 \%$ \\
\hline My coworkers keep the promises they make & $4,9 \%$ & $7,1 \%$ & $9,0 \%$ & $25,7 \%$ & $34,2 \%$ & $19,1 \%$ \\
\hline I trust in the skills of my coworkers & $3,9 \%$ & $4,4 \%$ & $7,6 \%$ & $27,1 \%$ & $37,7 \%$ & $19,3 \%$ \\
\hline There is cooperation among my coworkers & $7,1 \%$ & $5,1 \%$ & $6,9 \%$ & $25,0 \%$ & $38,0 \%$ & $17,9 \%$ \\
\hline My coworkers ask for each other's opinions when necessary & $5,9 \%$ & $5,1 \%$ & $6,9 \%$ & $24,3 \%$ & $39,5 \%$ & $18,4 \%$ \\
\hline $\begin{array}{l}\text { My coworkers help each other without any expectation in } \\
\text { return, in order reach their common goals }\end{array}$ & $7,1 \%$ & $8,6 \%$ & $7,3 \%$ & $22,7 \%$ & $36,4 \%$ & $17,8 \%$ \\
\hline $\begin{array}{l}\text { My coworkers do not reffain from asking for help when } \\
\text { they need it }\end{array}$ & $4,6 \%$ & $3,4 \%$ & $7,1 \%$ & $18,6 \%$ & $42,3 \%$ & $24,0 \%$ \\
\hline $\begin{array}{l}\text { My coworkers do not refrain from sharing the knowledge } \\
\text { they have about their work }\end{array}$ & $6,4 \%$ & $5,9 \%$ & $8,3 \%$ & $19,6 \%$ & $40,1 \%$ & $19,8 \%$ \\
\hline $\begin{array}{l}\text { If needed, my coworkers place the achievement of the team } \\
\text { goals above their own interests }\end{array}$ & $10,8 \%$ & $10,8 \%$ & $8,8 \%$ & $27,4 \%$ & $29,6 \%$ & $12,7 \%$ \\
\hline
\end{tabular}

